\title{
Guibert d'Andrenas, édité par Muriel Ott
}

\section{G. Matteo Roccati}

\section{OpenEdition}

\section{Journals}

Édition électronique

URL : http://journals.openedition.org/studifrancesi/27147

DOI : $10.4000 /$ studifrancesi. 27147

ISSN : 2421-5856

\section{Éditeur}

Rosenberg \& Sellier

\section{Édition imprimée}

Date de publication : 31 décembre 2006

Pagination : $572-573$

ISSN : 0039-2944

\section{Référence électronique}

G. Matteo Roccati, « Guibert d'Andrenas, édité par Muriel Ott », Studi Francesi [En ligne], 150 (L | III) | 2006, mis en ligne le 30 novembre 2015, consulté le 08 novembre 2020. URL : http://

journals.openedition.org/studifrancesi/27147 ; DOI : https://doi.org/10.4000/studifrancesi.27147

Ce document a été généré automatiquement le 8 novembre 2020.

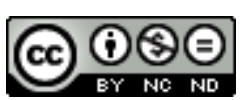

Studi Francesi è distribuita con Licenza Creative Commons Attribuzione - Non commerciale - Non opere derivate 4.0 Internazionale. 


\title{
Guibert d'Andrenas, édité par Muriel Ott
}

\author{
G. Matteo Roccati
}

\section{RÉFÉRENCE}

GUIBERT D’ANDRENAS, édité par Muriel OTT, Paris, Honoré Champion éditeur («Les

classiques français du Moyen Age», n 147), 2004, pp. 462.

1 Guibert d'Andrenas est une chanson de geste appartenant au cycle de Guillaume d'Orange. Elle n'est pas un «récit marginal» - son objet est l'acquisition de la royauté par Guibert, le plus jeune fils d'Aymeri de Narbonne - et elle appartient pleinement à la geste des enfants de ce dernier. Elle est conservée dans cinq manuscrits (dont un fragmentaire). L'édition est soignée; elle est basée sur le ms. Londres, B.L., Royal 20 D XI, et remplace celle procurée par J. Melander en 1922.

2 L'Introduction (pp. 11-214) présente les éditions antérieures et les manuscrits, procède au classement de ces derniers par une étude précise des variantes, examine la question de la date de la chanson (début du XIII ${ }^{\mathrm{e}} \mathrm{s}$.) et explicite les critères adoptés pour l'établissement du texte: respect de la leçon de base, sauf en cas d'irrégularité métrique. Suivent l'étude de la langue du manuscrit de base (pp. 42-93) et celle de la versification (pp. 93-115), ainsi qu'une analyse détaillée de la chanson, l'étude de son intérêt littéraire et la bibliographie.

3 Le texte (2387 vers: 70 laisses de décasyllabes rimés; chaque laisse se termine par un hexasyllabe orphelin), accompagné de l'indication des variantes en bas de page, est suivi des notes (pp. 353-402), du glossaire (pp. 403-447) et de l'index des noms propres (pp. 449-460). 